\title{
REVIEW KARAKTERISTIK MEKANIK DAN TOXICITY CHARACTERISTIC LEACHING PROCEDURE BETON GEOPOLIMER
}

\author{
(A Review on the Mechanical Properties and Toxicity Characteristic Leaching \\ Procedure in Geopolimer Concrete)
}

\author{
Ibnu Jamil Khairi ${ }^{1}$, L. Oksri-Nelfia ${ }^{1}$, Bambang Endro Yuwono ${ }^{1}$, Pratama Haditua Reyner Siregar ${ }^{1}$ \\ ${ }^{1}$ Jurusan Teknik Sipil Universitas Trisakti \\ E-mail: lisa@trisakti.ac.id
}

Diterima 29 Juli 2020, Disetujui 30 September 2020

\begin{abstract}
ABSTRAK
Beton Geopolimer merupakan beton yang menggunakan material anorganik produk sampingan hasil limbah padat industri yang disintesis melalui proses polimerisasi seperti fly ash, terak besi, terak nikel, dan material lainnya yang mengandung unsur Alumunium (Al) dan Silika (Si) yang tinggi. Produksi 1 ton semen Portland menghasilkan emisi gas $\mathrm{CO}_{2}$ sebesar 1 ton ke atmosfer sehingga dapat membahayakan lingkungan seperti pemanasan global. Tujuan dari studi literatur ini adalah untuk menunjukan bagaimana karakteristik mekanik pada beton geopolimer dalam penggunaan $100 \%$ produk sampingan limbah industri (ferrous dan non-ferrous) sebagai pengganti semen Portland sepenuhnya pada beton konvensional, serta meninjau dampak lingkungan yang ditimbulkan akibat penggunaan limbah tersebut dengan menggunakan analisis TCLP. Toxicity Characteristic Leaching Procedure (TCLP) merupakan prosedur untuk mengetahui kadar logam berat pada produk sampingan limbah industri (ferrous dan non-ferrous) yang dapat larut dan dapat mencemari lingkungan. Studi pustaka yang membahas material anorganik mengenai beton geopolimer secara holistik masih sedikit. Beberapa faktor yang dapat memengaruhi karakteristik mekanik beton geopolimer antara lain proporsi campuran, penggunaan admixture, pemilihan material anorganik, metode perawatan dan durasi perawatan, dan rasio larutan alkali sebagai aktivator. Proporsi campuran yang tepat dapat menghasilkan workability yang baik, kuat tekan, dan kuat tarik belah yang tinggi. Metode dan durasi perawatan dengan pemanasan (oven curing) mampu menghasilkan kekuatan mekanik yang lebih besar dibanding dengan metode perawatan suhu ruangan. Studi literatur ini diharapkan dapat memberikan pedoman dalam pengembangan beton geopolimer kedepannya bagi para peneliti dan industri.
\end{abstract}

Kata Kunci: Beton Geopolimer, Workability, Kuat Tekan, Kuat Tarik Belah, TCLP

\begin{abstract}
Geopolymer concrete is concrete that used inorganic byproducts of industrial solid waste such as fly ash, steel slag, nickel slag, and other materials that contain high aluminium (Al) and Silica (Si) elements synthesized through polimerization process. Production of 1 ton of Portland cement produces 1 ton of $\mathrm{CO}_{2}$ gas emissions into the atmosphere and can endanger the environment causing global warming. The purpose of this literature study is to show how the mechanical characteristics of geopolymer concrete by using $100 \%$ industrial waste by-products (ferrous and non-ferrous) as a replacement of Portland cement on conventional concrete, then to review the environmental impact caused by the use of such waste by using TCLP analysis. Toxicity Characteristic Leaching Procedure (TCLP) is a procedure to determine the levels of heavy metals in industrial waste by-products (ferrous and non-ferrous) which are soluble and can pollute the environment. There were few literature studies that discuss inorganic materials regarding geopolymer concrete in a holistic manner. Several factors can affect the mechanical characteristics of geopolymer concrete such as the proportion of the mixture, the use of admixture, the choice of inorganic material, the method of curing and the duration of curing, and the ratio of alkaline solution as an activator. The right proportion of mixture can produce good workability, compressive strength, and splitting tensile strength. The method and duration of treatment by heating (oven curing) is able to produce greater mechanical strength compared to the room temperature curing method. This literature review is expected to provide guidance in the future development of geopolymer concrete for researchers and industries.
\end{abstract}

Keywords: Geopolymer Concrete, Workability, Compressive Strength, Splitting Tensile Strength, TCLP 


\section{PENDAHULUAN}

Geopolimer merupakan klasifikasi pada material anorganik mengandung unsur silika dan alumina yang tinggi dan disintesis melalui proses polikondensasi menggunakan aktivator atau larutan alkali (Davidovits, 1991). Pada mulanya, material ini memiliki beberapa nama seperti inorganic polymer dan alkali-activated materials (AAM). Argumentasi lain menyebutkan bahwa geopolimer lebih mengarah kepada kandungan kalsium yang rendah (Davidovits 1991; Duxson dkk. 2007). Untuk mempermudah penyebutannya maka disimpulkan menggunakan satu nama yaitu geopolimer. Beton geopolimer yang dibahas pada studi literatur ini menggunakan material ferrous dan non-ferrous sebagai binders. Material ferrous yang digunakan adalah material logam seperti terak besi, sedangkan non-ferrous merupakan material non logam seperti abu sekam padi, fly ash, terak nikel, metakaolin yang biasanya bersifat pozzolan. Studi literatur ini membahas beton geopolimer yang tidak menggunakan semen Portland sama sekali dalam campuran beton tetapi digantikan oleh material ferrous dan non-ferrous. Alkali aktivator merupakan komponen yang sangat penting pada geopolimer. Davidovits \& Comrie (1988) menyatakan alkali cair dapat bereaksi dengan unsur Alumunium (Al) dan Silikon (Si) yang ditemukan pada produk sampingan hasil limbah padat seperi fly ash dan abu sekam padi untuk menghasilkan binders. Campuran antara material dengan larutan alkali harus tepat untuk mendapatkan hasil yang baik.

Alkali yang paling banyak digunakan pada penelitian adalah Natrium Hidroksida $(\mathrm{NaOH})$ dan Sodium Silikat $\left(\mathrm{Na}_{2} \mathrm{SiO}_{3}\right)$. Kandungan Silika dan Alumina dalam bentuk padatan kemudian diaktifkan menggunakan kombinasi larutan Natrium Silikat $\left(\mathrm{Na}_{2} \mathrm{SiO}_{3}\right)$ dan Natrium Hidroksida $(\mathrm{NaOH})$ sehingga membentuk pasta geopolimer yang dapat menjadi pengikat agregat dan bahan yang tidak reaktif lainnya (Hardjito dkk. 2004).

Beton geopolimer dapat meminimalisasi dampak negatif yang ditimbulkan terhadap lingkungan dibandingkan dengan beton konvensional. Penggunaan beton geopolimer dapat mengurangi emisi gas $\mathrm{CO}_{2}$ hingga $80 \%$ (Hassan dkk. 2019). Produksi semen skala global menghasilkan kontribusi emisi gas karbon dioksida $\left(\mathrm{CO}_{2}\right)$ sebesar $5-7 \%$ dari total emisi karbon dioksida $\left(\mathrm{CO}_{2}\right)$ ke atmosfir di bumi (McLellan dkk. 2011; Van Den Heede \& De Belie, 2012). Meningkatnya produksi gas $\mathrm{CO}_{2}$ secara terus menerus dapat menyebabkan peningkatan konsentrasi gas di atmosfer yang memicu terjadinya kenaikan temperatur bumi. Perbandingan antara beton geopolimer dan beton konvensional adalah kemampuan bertahan pada temperatur yang sangat rendah dan pada temperatur yang tinggi tanpa mengalami degradasi, pengaturan waktu ikat yang lebih mudah, dll (Hassan dkk. 2019).

Beton geopolimer memiliki sifat tekstur yang lengket dan memiliki nilai slump yang rendah, sehingga diperlukan bahan tambah dengan jumlah yang tepat untuk mendapatkan nilai workability yang diinginkan. Penelitian yang dilakukan Deb dkk. (2014) menyimpulkan bahwa penggunaan superplasticizer pada beton geopolimer dapat meningkatkan nilai slump pada kisaran $15 \mathrm{~cm}$ hingga $25 \mathrm{~cm}$. Dari segi karaketistik mekanik, beton geopolimer dapat mendekati bahkan melebihi kualitas yang dimiliki oleh beton konvensional. Penelitian Umniati dkk. (2017) menunjukkan bahwa pada umur beton 28 hari beton geopolimer berbasis fly ash dengan variasi benda uji yang berbeda menunjukan kuat tekan berada pada rentang 38-47 MPa. Penelitian Adam \& Horianto (2014), Hardjito \& Rangan (2005), Topark-Ngarm dkk. (2015) menunjukan hasil yang sejalan. Pengujian kuat tarik belah pada penelitian Topark-Ngarm dkk. (2015) menjelaskan bahwa beton geopolimer menunjukan hasil yang lebih tinggi daripada beton konvensional yang memiliki rentang kekuatan antara 3-4 $\mathrm{MPa}$ dengan variasi spesimen campuran yang berbeda. Penelitian lain yang menunjukan kuat tarik belah yang lebih tinggi dibandingkan dengan beton konvensional adalah Mehta \& Siddique (2018), dan Parveen dkk. (2018).

Toxicity Characteristic Leaching Procedure (TCLP) merupakan sebuah metode pengujian kadar metal seperti kandungan logam berat yang dapat terurai dan mencemari lingkungan. Pengujian TCLP dilakukan umumnya berdasarkan standar USEPA 1992 SW 846-1311 untuk mengukur jumlah kadar logam berat dan potensi mencemari lingkungan sebagai akibat penggunaan limbah padat industri ferrous dan non-ferrous pada beton geopolimer

Studi literatur ini ini akan membahas mengenai workability, kuat tarik belah, kuat tekan dan pengujian TCLP pada beton geopolimer. Faktorfaktor yang dapat memengaruhi pembahasan diatas adalah material precursor, superplasticizer, alkali aktivator, konsentrasi alkali aktivator serta metode dan durasi curing.

\section{METODE}

Penelitian ini menggunakan studi literatur dari penelitian-penelitian sebelumnya mengenai workability, kuat tarik belah, kuat tekan dan pengujian TCLP pada beton geopolimer. Datadata dan hasil dari penelitian terdahulu dirangkum berdasarkan karakteristik mekanistik beton yang selanjutnya dapat ditarik kesimpulan mengenai pengaruh metode TCLP terhadap karakterisik beton geopolimer. 


\section{HASIL DAN PEMBAHASAN}

\section{Prosedur dan Proporsi Beton Geopolimer}

Penelitian mengenai mix design yang tepat dalam produksi beton geopolimer masih terus dilakukan. Secara umum, proses produksi beton geopolimer adalah persiapan material precursor yang mengandung silika dan alumina yang tinggi seperti fly ash, metakaolin, GGBFS, kemudian persiapan agregat kasar dan halus. Selanjutnya, material precursor, aggregat halus, dan aggregat kasar dicampur. Persiapan larutan alkali yaitu $\mathrm{NaOH}$ padat dan cairan $\mathrm{Na}_{2} \mathrm{SiO}_{3}$ dicampur hingga larutan homogen. Kemudian campuran agregat dan material precursor dicampur larutan alkali, dan dilanjutkan dengan pelaksanaan curing pada beton sesuai metode dan durasi yang ditentukan (Hassan dkk. 2019). Tabel 1 menunjukan beberapa studi literatur terdahulu untuk proporsi mix design dan hasil pengujian karakteristik mekanik dengan pilihan metode oven curing atau ambient curing. Kandungan pada material yang berasal dari produk sampingan limbah padat perlu diuji untuk mengetahui kadar silika, alumina, dan unsur lainnya agar dapat dikategorikan sebagai material berbasis geopolimer.

Larutan alkali sebagai aktivator memiliki pengaruh yang signifikan pada kekuatan yang didapat. Perbandingan antara rasio aktivator $\mathrm{NaOH}$ dan $\mathrm{Na}_{2} \mathrm{SiO}_{3}$ serta konsentrasi molaritas $\mathrm{NaOH}$ yang digunakan memiliki karakteristik dan hasil yang berbeda beda tergantung dengan campuran lainnya. Perbedaan antara beton konvensional dan beton geopolimer adalah beton geopolimer tidak menggunakan semen sebagai binders dan tidak membutuhkan air dalam proses reaksi polikondensasi yang terjadi, tetapi reaksi tersebut menghasilkan air (Wallah \& Rangan, 2006). Material penyusun beton geopolimer akan melalui pengujian fisik dan kimia seperti Sieve Analysis, Specific Gravity, XRD, XRF, dan uji fisik lainnya. Metode ambient curing menyebabkan reaksi geopolimerisasi terjadi secara lamban, sehingga metode oven curing lebih dipilih pada produksi beton geopolimer (Kirschner \& Harmuth, 2004). Selama proses curing dengan pemanasan menggunakan oven berlangsung, reaksi polimerisasi akan lebih cepat terjadi. Sekitar 70\% kekuatan beton geopolimer dapat dicapai hanya dalam waktu 3-4 jam curing apabila dipaparkan dengan suhu tinggi (Kong et al., 2008). Peraturan mengenai mix design pada beton geopolimer belum ada, sehingga dibutuhkan penelitian lebih lanjut (Ferdous dkk., 2015). Standar prosedur pengujian kekuatan mekanik yang digunakan pada studi literatur ini adalah ASTM C39, ASTM C496, IS: 516 (1959).

Pada Tabel 1 dapat dilihat terdapat beberapa faktor yang dapat memengaruhi workability, kuat tekan, dan kuat tarik belah beton geopolimer.
Material GGBFS dan nano silica dapat meningkatkan kuat tekan dan kuat tarik belah beton geopolimer. Penggunaan material terak nikel, metakaolin, dan abu sekam padi juga dapat meningkatkan kuat tekan dan kuat tarik belah, namun penggunaan kadar yang berlebihan dapat menurunkan kekuatannya. Penggunaan superplasticizer dapat memengaruhi workability pada beton segar. Terbukti bahwa meningkatkan kadar superplasticizer dapat meningkatkan workability beton geopolimer. Superplasticizer juga dapat memengaruhi kuat tekan namun tidak signifikan. Rasio $\mathrm{Na}_{2} \mathrm{SiO}_{3} / \mathrm{NaOH}$ dapat memengaruhi kuat tekan dan kuat tarik belah beton geopolimer. Untuk mendapatkan kuat tekan yang lebih tinggi, metode curing yang lebih baik digunakan adalah oven curing daripada ambient curing.

\section{Workability}

Reaksi polimerisasi pada beton geopolimer tidak membutuhkan peranan air, sebaliknya hasil dari reaksi polimerisasi salah satunya adalah air (Hardjito \& Rangan, 2005). Air dapat memengaruhi kinerja (workability) pada beton segar. Penelitian Chindaprasirt dkk. (2007) menunjukan bahwa pengujian slump pada beton geopolimer berada pada rentang 115-135 mm. Hasil tersebut dipengaruhi oleh konsentrasi $\mathrm{NaOH}$ juga rasio $\mathrm{Na}_{2} \mathrm{SiO}_{3} / \mathrm{NaOH}$ yang digunakan. Penelitian Nath \& Sarker (2014) menunjukkan meningkatkan rasio aktivator dapat menurunkan nilai slump (Lihat Tabel 1).

Hardjito \& Rangan (2005) meneliti peran superplasticizer dalam upaya untuk meningkatkan workability pada beton geopolimer. Superplasticizer jenis polikarboksilat tidak menunjukan perbedaan yang signifikan terhadap workability dibandingkan dengan superplasticizer jenis naftalena. Demie dkk. (2013) meneliti pengaruh superplasticizer terhadap workability beton geopolimer berbasis GGBFS (Lihat Tabel 1). Penelitian tersebut menunjukan bahwa meningkatkan kadar superplasticizer ke dalam campuran dapat meningkatkan workability pada beton geopolimer dan dapat mempengaruhi kuat tekan beton geopolimer. Penelitian yang sejalan juga ditemukan pada penelitian Jithendra \& Elavenil (2019) dan Vora \& Dave (2013). Penelitian Nuruddin dkk. (2011) menunjukan dengan molaritas $\mathrm{NaOH}$ sebesar $14 \mathrm{M}$ dan tambahan $6 \%$ superplasticizer dapat meningkatkan workability beton geopolimer.

Ketika persentase superplasticizer dalam campuran ditingkatkan, kuat tekan meningkat. Hal ini dikarenakan superplasticizer secara efektif dapat meningkatkan workability. Pengaruh molaritas $\mathrm{NaOH}$ yang ditingkatkan berdampak pada penurunan workability. Kombinasi antara GGBFS dan fly ash juga dapat 
berpengaruh pada nilai workability beton geopolimer. Penelitian Nath \& Sarker (2014) menunjukan bahwa menambahkan campuran GGBFS dapat menurunkan nilai slump (Lihat Tabel 1). Bila dibandingkan dengan GGBFS, fly ash lebih baik dalam meningkatkan workability beton geopolimer. Hal ini dipengaruhi oleh bentuk partikel GGBFS yang tidak beraturan dibandingkan dengan bentuk partikel fly ash yang bulat dan kandungan kalsium yang tinggi pada GGBFS dapat mempercepat reaksi (Xie dkk., 2019).

\section{Kuat Tekan}

Beton geopolimer memiliki kelebihan yaitu kuat tekan pada umur awal beton mampu menyamai bahkan lebih tinggi daripada beton konvensional (Farhan dkk., 2019). Jika dibandingkan dengan beton konvensional dengan menggunakan metode ambient curing, kuat tekan yang didapat pada beton geopolimer mampu lebih tinggi. Hal ini dikarenakan reaksi polimerisasi distimulasi oleh kandungan kalsium (Ca) yang terdapat pada material precursor (Nath dkk., 2015; Neupane, 2018; Yip dkk., 2008). Rangan (2008) menyarankan penggunaan rasio larutan alkali/binder yang digunakan berkisar 0.35-0.55 pada beton geopolimer berbasis fly ash. Penelitian Jawahar J. G. (2015) menjelaskan bahwa kuat tekan yang lebih tinggi dapat diperoleh dengan meningkatkan persentase GGBFS daripada persentase fly ash (Lihat Tabel 1). Pada Tabel 1, penelitian Abdul Sani dkk. (2020) menunjukan pencampuran fly ash dan GGBFS dengan kadar GGBFS yang lebih dominan menghasilkan kuat tekan yang lebih tinggi dibandingkan dengan kadar fly ash yang dominan. Hal ini dikarenakan kandungan $\mathrm{Ca}^{2+}$ pada fly ash yang lebih sedikit dibandingkan dengan GGBFS sehingga reaksi polikondensasi yang terjadi tidak dapat meningkatkan kuat tekan pada beton geopolimer (Xie dkk., 2019). Dapat disimpulkan bahwa dengan peningkatan subtitusi GGBFS pada fly ash didapatkan beton mutu tinggi. Menggunakan GGBFS dan nano silica dapat memengaruhi kuat tekan pada beton geopolimer (Saini \& Vattipalli, 2020). Kuat tekan yang mampu dicapai dengan menggunakan GGBFS dan nano silica tersebut adalah sebesar $\pm 70.6 \mathrm{MPa}$ pada umur beton 28 hari (Lihat Tabel 1). Nano silica yang reaktif sepenuhnya pada struktur alumino silikat dapat memengaruhi kuat tekan. Yang dkk. (2014) meneliti pengaruh penggunaan High Magnesium Nickel Slag (HMNS) pada beton geopolimer berbasis fly ash. Penggunaan HMNS yang tidak tepat dapat menurunkan kuat tekan beton geopolimer. Cao dkk. (2018) menguji karakteristik beton dengan kombinasi GGBFS dan ferronickel slag dengan metode ambient curing. Hasil yang didapat adalah menurunnya kuat tekan beton dengan penambahan persentase ferronickel slag.
Gambar 1 juga menunjukan pengaruh persentase ferronickel slag pada kuat tekan beton geopolimer. Kuat tekan beton selalu naik seiring bertambahnya umur beton.

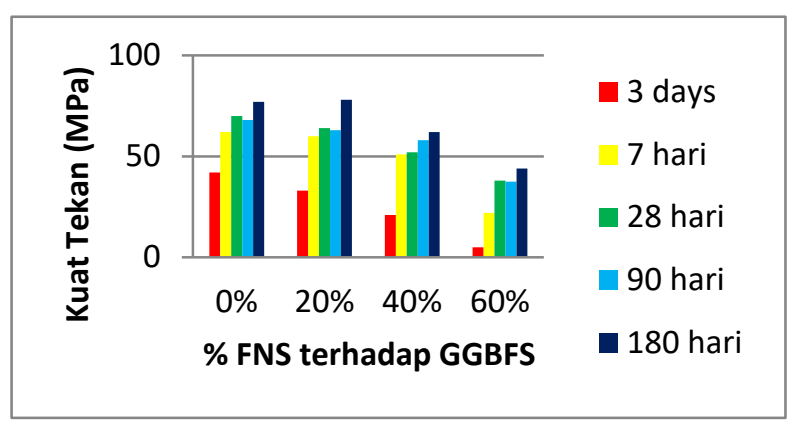

Gambar 1. Pengaruh ferronickel slag pada kuat tekan

Sumber: (Cao et al., 2018)

Kuat tekan pada beton geopolimer juga dapat dipengaruhi oleh rasio alkali aktivator $\mathrm{Na}_{2} \mathrm{SiO}_{3} / \mathrm{NaOH}$. Penelitian Topark-Ngarm dkk. (2015), dan Vora \& Dave (2013) menunjukan bahwa rasio alkali aktivator sebesar 1 sampai 2 dapat meningkatkan kuat tekan. Sebaliknya, rasio alkali aktivator sebesar 2,5 dapat menyebabkan penurunan kuat tekan pada beton geopolimer. Hal ini terjadi karena banyaknya jumlah silika yang dilarutkan pada larutan natrium silikat sehingga menghambat proses geopolimerisasi (Thaarrini \& Venkatasubramani, 2015). Gambar 2 menunjukan pengaruh rasio alkali aktivator terhadap kuat tekan.

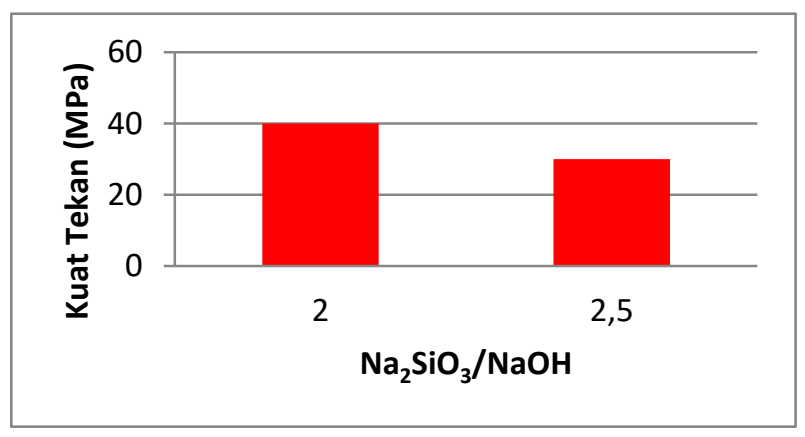

Gambar 2. Pengaruh rasio $\mathrm{Na}_{2} \mathrm{SiO}_{3} / \mathrm{NaOH}$

terhadap kuat tekan

Sumber: (Vora \& Dave, 2013)

Faktor lainnya yang dapat memengaruhi kuat tekan adalah curing. Topark-Ngarm dkk. (2015) membandingkan kuat tekan beton geopolimer menggunakan ambient curing dan oven curing (Lihat Tabel 1). Hasil yang didapat adalah beton dengan metode oven curing memiliki kuat tekan yang lebih tinggi daripada metode ambient curing. Penggunaan metode ambient curing lebih mudah diaplikasikan pada skala yang lebih besar (pembangunan infrastruktur) dibandingkan dengan oven curing. Namun kuat tekan dengan menggunakan metode oven curing mampu menghasilkan kuat tekan yang lebih tinggi (Lihat Tabel 1). Penelitian Lloyd \& Rangan (2010) 
menjelaskan pengaruh oven curing pada suhu $60^{\circ} \mathrm{C}$ dengan variasi durasi selama 4 jam hingga 96 jam pada beton geopolimer berbasis fly ash. Lloyd \& Rangan (2010) menunjukan durasi curing pada beton geopolimer. Hasilnya adalah durasi curing selama 4-24 jam menunjukan hasil yang lebih signifikan dibandingkan dengan durasi curing yang melebihi 24 jam. 75\% kuat tekan total didapat pada durasi curing selama 24 jam. Gambar 3 menunjukan penambahan kuat tekan setelah waktu curing melebihi 24 jam tidak terlalu signifikan, sehingga dalam oven curing dengan durasi melebihi 24 jam tidak diperlukan.

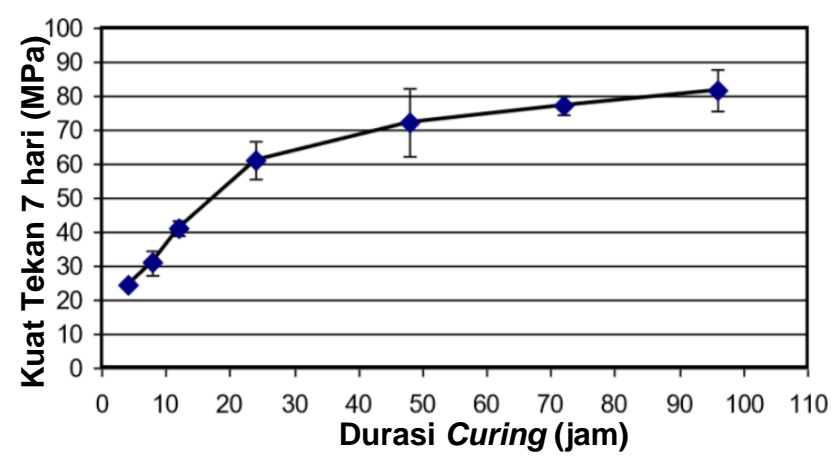

Gambar 3. Durasi oven curing terhadap kuat tekan

Sumber: (Lloyd \& Rangan, 2010)

\section{Kuat Tarik Belah}

Kuat tarik belah merupakan karakteristik mekanik yang perlu diperhatikan pada beton geopolimer. Pengujian ini dilakukan dengan pemberian beban secara lateral terhadap benda uji beton silinder. Penelitian Bouaissi dkk. (2019) menunjukan bahwa kuat tarik belah pada beton geopolimer memiliki korelasi dengan kuat tekan. Hal ini ditandai dengan kuat tarik belah yang meningkat seiring dengan pertambahan umur beton sama seperti kuat tekan pada beton geopolimer.

Tabel 1 menunjukan kuat tarik belah pada beton geopolimer berbasis fly ash dapat ditingkatkan dengan penambahan campuran GGBFS (Abdul Sani dkk., 2020). Hasil yang serupa diperoleh pada penelitian Jawahar J. G. (2015) yang membahas pengaruh GGBFS terhadap kuat tarik belah pada beton geopolimer berbasis fly ash menggunakan metode ambient curing. Gambar 4 menunjukan persentase penggunaan GGBFS sebesar 50\%, 75\%, dan $100 \%$ dapat meningkatkan kuat tarik belah.

Penelitian Saini \& Vattipalli (2020) menunjukan kuat tarik belah pada beton geopolimer yang berbasis fly ash dapat dipengaruhi oleh nano silica dan molaritas $\mathrm{NaOH}$ yang digunakan (Lihat Tabel 1). Gambar 5 menunjukan penambahan nano silica sebesar $2 \%$ dan molaritas $\mathrm{NaOH}$ sebesar 16M memiliki nilai kuat tarik belah yang paling tinggi di antara variasi benda uji. Kuat tarik belah yang dicapai cukup tinggi yaitu 6,4 MPa saat umur benda uji 90 hari. Dapat disimpulkan bahwa molaritas $\mathrm{NaOH}$, GGBFS dan nano silica berperan penting terhadap kuat tarik belah. Penggunaan material lain seperti metakaolin juga berpengaruh pada kuat tarik belah beton geopolimer. Nuaklong dkk. (2018) meneliti beton geopolimer menggunakan limestone dan agregat daur ulang dengan campuran fly ash dan metakaolin (Tabel 1). Dengan kombinasi campuran fly ash, GGBFS, dan metakaolin, kuat tarik belah dan kepadatan mikrostruktur beton geopolimer dapat ditingkatkan.

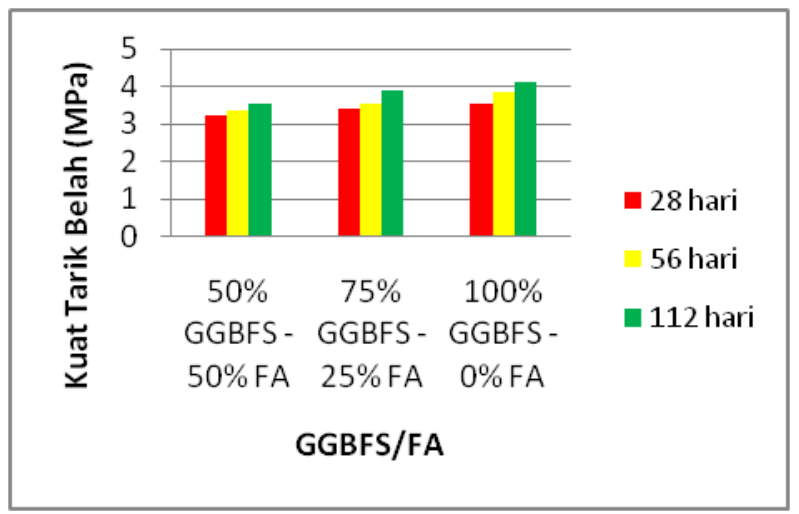

Gambar 4. Pengaruh GGBFS terhadap kuat tarik belah dengan metode ambient curing

Sumber: (Jawahar and Mounika, 2015)

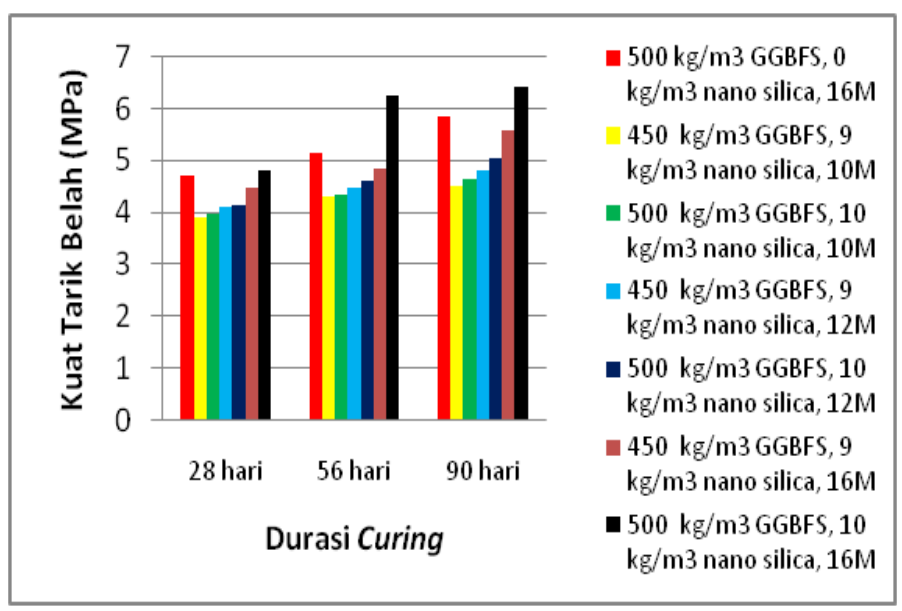

Gambar 5. Pengaruh molaritas, GGBFS, dan nano silica terhadap kuat tarik belah dengan metode ambient curing

Sumber: (Saini and Vattipali, 2020) 
Review Karakteristik Mekanik dan Toxicity. ..Ibnu J K, L. Oksri-Nelfia, Bambang E Y, Pratama H R S

Tabel 1. Mix Design dan Hasil Pengujian Karakteristik Mekanik Beton Geopolimer

\begin{tabular}{|c|c|c|c|c|c|c|c|c|c|c|c|c|c|c|c|c|c|c|c|}
\hline \multirow{3}{*}{ Referensi } & \multirow{3}{*}{$\begin{array}{c}\mathrm{FA} \\
\left(\mathrm{kg} / \mathrm{m}^{3}\right)\end{array}$} & \multirow{3}{*}{$\begin{array}{l}\text { GGBFS } \\
\left(\mathrm{kg} / \mathrm{m}^{3}\right)\end{array}$} & \multirow{3}{*}{$\begin{array}{c}\mathrm{NS} \\
\left(\mathrm{kg} / \mathrm{m}^{3}\right)\end{array}$} & \multirow{3}{*}{$\begin{array}{l}\text { HMNS } \\
\left(\mathrm{kg} / \mathrm{m}^{3}\right)\end{array}$} & \multirow{3}{*}{$\begin{array}{c}\mathrm{MK} \\
\left(\mathrm{kg} / \mathrm{m}^{3}\right)\end{array}$} & \multirow{3}{*}{$\begin{array}{c}\mathrm{RHA} \\
\left(\mathrm{kg} / \mathrm{m}^{3}\right)\end{array}$} & \multicolumn{2}{|c|}{$\begin{array}{c}\text { Aggregat } \\
\left(\mathrm{kg} / \mathrm{m}^{3}\right)\end{array}$} & \multicolumn{2}{|c|}{$\begin{array}{l}\text { Alkali Aktivator } \\
\left(\mathrm{kg} / \mathrm{m}^{3}\right)\end{array}$} & \multirow{3}{*}{$\begin{array}{l}\text { Molaritas } \\
\text { (M) }\end{array}$} & \multirow{3}{*}{$\begin{array}{l}\text { SP } \\
(\%)\end{array}$} & \multirow{3}{*}{$\begin{array}{c}\text { Tambahan } \\
\text { air } \\
\left(\mathrm{kg} / \mathrm{m}^{3}\right)\end{array}$} & \multicolumn{2}{|c|}{ Curing } & \multirow{3}{*}{$\begin{array}{c}\begin{array}{c}\text { Slump } \\
\text { Flow }\end{array} \\
(\mathrm{mm})\end{array}$} & \multirow{3}{*}{$\begin{array}{l}\text { Slump } \\
(\mathrm{mm})\end{array}$} & \multirow{3}{*}{$\begin{array}{c}\text { Kuat } \\
\text { Tekan } \\
\text { (MPa) }\end{array}$} & \multirow{3}{*}{$\begin{array}{l}\text { Kuat } \\
\text { Tarik } \\
\text { Belah } \\
\text { (MPa) }\end{array}$} \\
\hline & & & & & & & & & & & & & & Durasi & Suhu & & & & \\
\hline & & & & & & & Kasar & Halus & $\mathrm{Na}_{2} \mathrm{SiO}_{3}$ & $\mathrm{NaOH}$ & & & & (hari) & ${ }^{0} \mathrm{C}$ & & & & \\
\hline \multirow{3}{*}{$\begin{array}{l}\text { (Jawahar } \\
\text { J. G, 2015) }\end{array}$} & 204,5 & 204,5 & - & - & - & - & 1293 & 554 & 102 & 41 & 10 & - & 55 & 28 & AT & - & - & 53,5 & 3,25 \\
\hline & 102 & 307 & - & - & - & - & 1293 & 554 & 102 & 41 & 10 & - & 55 & 28 & AT & - & - & 55,5 & 3,39 \\
\hline & 0 & 409 & - & - & - & - & 1293 & 554 & 102 & 41 & 10 & - & 55 & 28 & AT & - & - & 58,6 & 3,54 \\
\hline \multirow{2}{*}{$\begin{array}{c}\text { (Bouaissi } \\
\text { dkk. } \\
\text { 2019a) } \\
\end{array}$} & & 96 & - & 48 & - & - & 1176 & 504 & 171.43 & 68,6 & 12 & - & - & 28 & AT & - & 218 & 55,6 & - \\
\hline & 222,6 & 63,6 & - & 31,8 & - & - & 779 & 333,7 & 113,6 & 45,5 & 12 & - & - & 28 & AT & - & 218 & - & 4,57 \\
\hline \multirow{5}{*}{$\begin{array}{l}\text { (Patel \& } \\
\text { Shah, } \\
\text { 2018) }\end{array}$} & 500 & - & - & - & - & - & 785 & 1100 & 163 & 65 & 12 & 6 & 25 & 28 & AT & 720 & - & 20 & - \\
\hline & - & 500 & - & - & - & - & 785 & 1100 & 163 & 65 & 12 & 6 & 25 & 28 & AT & 710 & - & 41,35 & - \\
\hline & - & 475 & - & - & - & 25 & 785 & 1100 & 163 & 65 & 12 & 6 & 25 & 28 & AT & 690 & - & 42,6 & - \\
\hline & - & 425 & - & - & - & 75 & 785 & 1100 & 163 & 65 & 12 & 6 & 25 & 28 & AT & 680 & - & 39,31 & - \\
\hline & - & 375 & - & - & - & 125 & 785 & 1100 & 163 & 65 & 12 & 6 & 25 & 28 & AT & 655 & - & 31,59 & - \\
\hline \multirow{9}{*}{$\begin{array}{l}\text { (Nath \& } \\
\text { Sarker, } \\
\text { 2014) }\end{array}$} & 400 & 0 & - & - & - & - & 1209 & 651 & 114,3 & 45,7 & 14 & - & - & 28 & AT & - & \pm 250 & $\pm 25,9$ & - \\
\hline & 360 & 40 & - & - & - & - & 1209 & 651 & 114,3 & 45,7 & 14 & - & - & 28 & AT & - & \pm 230 & $\pm 34,8$ & - \\
\hline & & & - & - & - & - & & & & & & & & 1 & 60 & - & & $\pm 45,8$ & - \\
\hline & 320 & 80 & - & - & - & - & 1209 & 651 & 114,3 & 45,7 & 14 & - & - & 28 & AT & - & \pm 230 & $\pm 45,8$ & - \\
\hline & 280 & 120 & - & - & - & - & 1209 & 651 & 114,3 & 45,7 & 14 & - & - & 28 & AT & - & \pm 210 & $\pm 54,4$ & - \\
\hline & 360 & 40 & - & - & - & - & 1209 & 651 & 100 & 40 & 14 & - & - & 28 & AT & - & $\pm 95,4$ & \pm 46 & - \\
\hline & 360 & 40 & - & - & - & - & 1209 & 651 & 128,5 & 51,5 & 14 & - & - & 28 & AT & - & $\pm 233,3$ & $\pm 30,67$ & - \\
\hline & 360 & 40 & - & - & - & - & 1209 & 651 & 96 & 64 & 14 & - & - & 28 & AT & - & \pm 245 & $\pm 35,5$ & - \\
\hline & 360 & 40 & - & - & - & - & 1209 & 651 & 106,7 & 53,5 & 14 & - & - & 28 & AT & - & \pm 240 & \pm 34 & - \\
\hline
\end{tabular}




\begin{tabular}{|c|c|c|c|c|c|c|c|c|c|c|c|c|c|c|c|c|c|c|c|}
\hline \multirow[t]{2}{*}{ Referensi } & \multirow{2}{*}{$\begin{array}{c}\mathrm{FA} \\
\left(\mathrm{kg} / \mathrm{m}^{3}\right)\end{array}$} & \multirow{2}{*}{$\begin{array}{l}\text { GGBFS } \\
\left(\mathrm{kg} / \mathrm{m}^{3}\right)\end{array}$} & \multirow{2}{*}{$\begin{array}{c}\mathrm{NS} \\
\left(\mathrm{kg} / \mathrm{m}^{3}\right)\end{array}$} & \multirow{2}{*}{$\begin{array}{l}\text { HMNS } \\
\left(\mathrm{kg} / \mathrm{m}^{3}\right)\end{array}$} & \multirow{2}{*}{$\begin{array}{c}\mathrm{MK} \\
\left(\mathrm{kg} / \mathrm{m}^{3}\right)\end{array}$} & \multirow{2}{*}{$\begin{array}{c}\mathrm{RHA} \\
\left(\mathrm{kg} / \mathrm{m}^{3}\right)\end{array}$} & \multicolumn{2}{|c|}{$\begin{array}{l}\text { Aggregat } \\
\left(\mathrm{kg} / \mathrm{m}^{3}\right)\end{array}$} & \multicolumn{2}{|c|}{$\begin{array}{c}\text { Alkali Aktivator } \\
\left(\mathrm{kg} / \mathrm{m}^{3}\right)\end{array}$} & \multirow{2}{*}{$\begin{array}{l}\text { Molaritas } \\
\text { (M) }\end{array}$} & \multirow{2}{*}{$\begin{array}{l}\text { SP } \\
(\%)\end{array}$} & \multirow{2}{*}{$\begin{array}{c}\begin{array}{c}\text { Tambahan } \\
\text { air }\end{array} \\
\left(\mathrm{kg} / \mathrm{m}^{3}\right)\end{array}$} & \multicolumn{2}{|c|}{ Curing } & \multirow{2}{*}{$\begin{array}{l}\text { Slump } \\
\text { Flow } \\
(\mathrm{mm})\end{array}$} & \multirow{2}{*}{$\begin{array}{l}\text { Slump } \\
(\mathrm{mm})\end{array}$} & \multirow{2}{*}{$\begin{array}{c}\text { Kuat } \\
\text { Tekan } \\
\text { (MPa) }\end{array}$} & \multirow{2}{*}{$\begin{array}{l}\text { Kuat } \\
\text { Tarik } \\
\text { Belah } \\
(\mathrm{MPa})\end{array}$} \\
\hline & & & & & & & Kasar & Halus & $\mathrm{Na}_{2} \mathrm{SiO}_{3}$ & $\mathrm{NaOH}$ & & & & (hari) & ${ }^{0} \mathrm{C}$ & & & & \\
\hline \multirow{6}{*}{$\begin{array}{c}\text { (Topark- } \\
\text { Ngarm } \\
\text { dkk. 2015) }\end{array}$} & 414 & - & - & - & - & - & 1091 & 588 & 104 & 104 & 10 & - & - & $\begin{array}{c}28 \\
1\end{array}$ & $\begin{array}{c}\text { AT } \\
60 \pm 2\end{array}$ & 580 & - & $\begin{array}{l}39,67 \\
46,67\end{array}$ & - \\
\hline & 414 & - & - & - & - & - & 1091 & 588 & 104 & 104 & 15 & - & - & $\begin{array}{c}28 \\
1\end{array}$ & $\begin{array}{c}\text { AT } \\
60 \pm 2\end{array}$ & 560 & - & $\begin{array}{c}45,34 \\
54,4\end{array}$ & - \\
\hline & 414 & - & - & - & - & - & 1091 & 588 & 104 & 104 & 20 & - & - & $\begin{array}{c}28 \\
1\end{array}$ & $\begin{array}{c}\text { AT } \\
60 \pm 2\end{array}$ & 470 & - & $\begin{array}{l}37,64 \\
43,42\end{array}$ & - \\
\hline & 414 & - & - & - & - & - & 1091 & 588 & 138 & 69 & 10 & - & - & $\begin{array}{c}28 \\
1\end{array}$ & $\begin{array}{c}\text { AT } \\
60 \pm 2\end{array}$ & 500 & - & $\begin{array}{c}33,8 \\
40,09\end{array}$ & - \\
\hline & 414 & - & - & - & - & - & 1091 & 588 & 138 & 69 & 15 & - & - & $\begin{array}{c}28 \\
1\end{array}$ & $\begin{array}{c}\text { AT } \\
60 \pm 2\end{array}$ & 550 & - & $\begin{array}{l}39,02 \\
48,18\end{array}$ & - \\
\hline & 414 & - & - & - & - & - & 1091 & 588 & 138 & 69 & 20 & - & - & $\begin{array}{c}28 \\
1 \\
\end{array}$ & $\begin{array}{c}\text { AT } \\
60 \pm 2 \\
\end{array}$ & 530 & - & $\begin{array}{c}46,69 \\
49,5 \\
\end{array}$ & - \\
\hline \multirow{12}{*}{$\begin{array}{c}\text { (Venkates } \\
\text { an \& } \\
\text { Pazhani, } \\
\text { 2016) }\end{array}$} & - & & & & & & & & & & & & & 28 & AT & & & 52,79 & - \\
\hline & - & 394 & - & - & - & - & 1201 & 647 & 113 & 45 & 8 & 1,5 & 59 & 0,667 & 60 & - & - & 69,28 & 6.74 \\
\hline & - & & & & & & & & & & & & & 0,667 & 90 & & & 71,63 & - \\
\hline & - & & & & & & & & & & & & & 28 & AT & & & 48,44 & - \\
\hline & - & 355 & - & - & - & 39 & 1201 & 647 & 113 & 45 & 8 & 1,5 & 59 & 0,667 & 60 & - & - & 70,72 & 6.92 \\
\hline & - & & & & & & & & & & & & & 0,667 & 90 & & & 72,34 & - \\
\hline & - & & & & & & & & & & & & & 28 & AT & & & 18,67 & - \\
\hline & - & 315 & - & - & - & 79 & 1201 & 647 & 113 & 45 & 8 & 1,5 & 59 & 0,667 & 60 & - & - & 51,46 & 4.26 \\
\hline & - & & & & & & & & & & & & & 0,667 & 90 & & & 52,66 & - \\
\hline & - & & & & & & & & & & & & & 28 & AT & & & 15,11 & - \\
\hline & - & 276 & - & - & - & 118 & 1201 & 647 & 113 & 45 & 8 & 1,5 & 59 & 0,667 & 60 & - & - & 24,52 & 1.12 \\
\hline & - & & & & & & & & & & & & & 0,667 & 90 & & & 16,1 & - \\
\hline
\end{tabular}




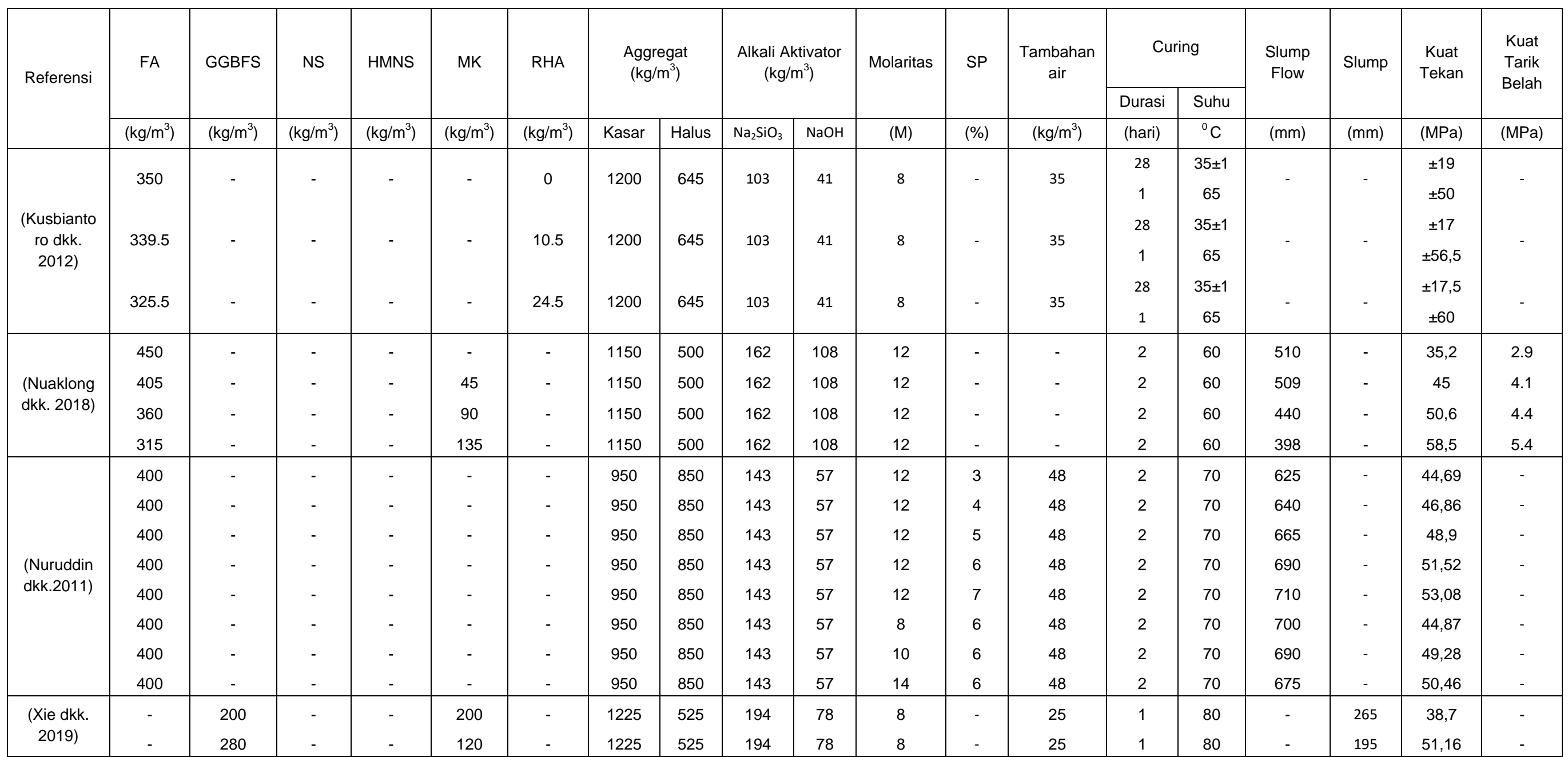




\begin{tabular}{|c|c|c|c|c|c|c|c|c|c|c|c|c|c|c|c|c|c|c|c|}
\hline \multirow[t]{3}{*}{ Referensi } & \multirow{3}{*}{$\begin{array}{c}\mathrm{FA} \\
\left(\mathrm{kg} / \mathrm{m}^{3}\right)\end{array}$} & \multirow{3}{*}{$\begin{array}{l}\text { GGBFS } \\
\left(\mathrm{kg} / \mathrm{m}^{3}\right)\end{array}$} & \multirow{3}{*}{$\begin{array}{c}\mathrm{NS} \\
\left(\mathrm{kg} / \mathrm{m}^{3}\right)\end{array}$} & \multirow{3}{*}{$\begin{array}{l}\text { HMNS } \\
\left(\mathrm{kg} / \mathrm{m}^{3}\right)\end{array}$} & \multirow{3}{*}{$\begin{array}{c}\text { MK } \\
\left(\mathrm{kg} / \mathrm{m}^{3}\right)\end{array}$} & \multirow{3}{*}{$\begin{array}{c}\mathrm{RHA} \\
\left(\mathrm{kg} / \mathrm{m}^{3}\right)\end{array}$} & \multicolumn{2}{|c|}{$\begin{array}{c}\text { Aggregat } \\
\left(\mathrm{kg} / \mathrm{m}^{3}\right)\end{array}$} & \multicolumn{2}{|c|}{$\begin{array}{l}\text { Alkali Aktivator } \\
\qquad\left(\mathrm{kg} / \mathrm{m}^{3}\right)\end{array}$} & \multirow{3}{*}{$\begin{array}{c}\text { Molaritas } \\
\text { (M) }\end{array}$} & \multirow{3}{*}{$\begin{array}{l}\text { SP } \\
(\%)\end{array}$} & \multirow{3}{*}{$\begin{array}{c}\begin{array}{c}\text { Tambahan } \\
\text { air }\end{array} \\
\left(\mathrm{kg} / \mathrm{m}^{3}\right)\end{array}$} & \multicolumn{2}{|c|}{ Curing } & \multirow{3}{*}{$\begin{array}{c}\text { Slump } \\
\text { Flow } \\
(\mathrm{mm})\end{array}$} & \multirow{3}{*}{$\begin{array}{l}\text { Slump } \\
(\mathrm{mm})\end{array}$} & \multirow{3}{*}{$\begin{array}{l}\text { Kuat } \\
\text { Tekan } \\
\text { (MPa) }\end{array}$} & \multirow{3}{*}{$\begin{array}{l}\text { Kuat } \\
\text { Tarik } \\
\text { Belah } \\
(\mathrm{MPa})\end{array}$} \\
\hline & & & & & & & & & & & & & & Durasi & Suhu & & & & \\
\hline & & & & & & & Kasar & Halus & $\mathrm{Na}_{2} \mathrm{SiO}_{3}$ & $\mathrm{NaOH}$ & & & & (hari) & ${ }^{0} \mathrm{C}$ & & & & \\
\hline \multirow{7}{*}{$\begin{array}{c}\text { (Saini \& } \\
\text { Vattipalli, } \\
\text { 2020) }\end{array}$} & - & 500 & 0 & - & - & - & 825 & 825 & 160,71 & 28,57 & 16 & 1,2 & 48,34 & 1 & 60 & 660 & - & \pm 60 & \pm 4.71 \\
\hline & - & 450 & 9 & - & - & - & 825 & 825 & 144,65 & 18,17 & 10 & 1,2 & 52,25 & 1 & 60 & 660 & - & $\pm 47,6$ & \pm 3.9 \\
\hline & - & 500 & 10 & - & - & - & 825 & 825 & 160,75 & 20,19 & 10 & 1,2 & 55,97 & 1 & 60 & 665 & - & $\pm 47,8$ & \pm 4 \\
\hline & - & 450 & 9 & - & - & - & 825 & 825 & 144,65 & 20,78 & 12 & 1,2 & 59,7 & 1 & 60 & 665 & - & $\pm 50,6$ & \pm 4.05 \\
\hline & - & 500 & 10 & - & - & - & 825 & 825 & 160,75 & 23,21 & 12 & 1,2 & 54,5 & 1 & 60 & 670 & - & \pm 52 & \pm 4.1 \\
\hline & - & 450 & 9 & - & - & - & 825 & 825 & 144,65 & 25,69 & 16 & 1,2 & 58,39 & 1 & 60 & 660 & - & \pm 56 & \pm 4.42 \\
\hline & - & 500 & 10 & - & - & - & 825 & 825 & 160,75 & 28,55 & 16 & 1,2 & 62,32 & 1 & 60 & 670 & - & $\pm 70,6$ & \pm 4.76 \\
\hline \multirow{3}{*}{$\begin{array}{l}\text { (Abdul } \\
\text { Sani dkk. } \\
\text { 2020) }\end{array}$} & 500 & - & - & - & - & - & 1060 & 707 & \multicolumn{2}{|c|}{150} & 14 & - & 74 & 1 & 60 & - & 97 & 32,8 & 2.08 \\
\hline & 450 & 50 & - & - & - & - & 1060 & 707 & \multicolumn{2}{|c|}{150} & 14 & - & 74 & 1 & 60 & - & 101 & 48,9 & 2.65 \\
\hline & 400 & 100 & - & - & - & - & 1060 & 707 & \multicolumn{2}{|c|}{150} & 14 & - & 74 & 1 & 60 & - & 102 & 53,2 & 2.77 \\
\hline \multirow{5}{*}{$\begin{array}{c}\text { (Demie } \\
\text { dkk. 2013) }\end{array}$} & 400 & - & - & - & - & - & 950 & 850 & 143 & $\begin{array}{l}5 \\
7\end{array}$ & 12 & 3 & 48 & 2 & 70 & 625 & - & 44,69 & - \\
\hline & 400 & - & - & - & - & - & 950 & 850 & 143 & 7 & 12 & 4 & 48 & 2 & 70 & 640 & - & 46,86 & - \\
\hline & 400 & - & - & - & - & - & 950 & 850 & 143 & 7 & 12 & 5 & 48 & 2 & 70 & 665 & - & 48,9 & - \\
\hline & 400 & - & - & - & - & - & 950 & 850 & 143 & 7 & 12 & 6 & 48 & 2 & 70 & 690 & - & 51,52 & - \\
\hline & 400 & - & - & - & - & - & 950 & 850 & 143 & 7 & 12 & 7 & 48 & 2 & 70 & 710 & - & 53,08 & - \\
\hline
\end{tabular}

Keterangan: FA = Fly Ash; GGBFS = Ground Granulated Blast Furnace Slag; NS = Nano Silica; MK = Metakaolin; HMNS = High Magnesium Nickel Slag; RHA = Rice Husk Ash; SP = Superplasticizer; AT = Ambient Temperature 
TCLP

Toxicity Characteristic Leaching Procedure (TCLP) bertujuan untuk mengetahui potensi terjadinya leaching atau perlindian logam berat pada limbah padat industri yang dapat mencemari lingkungan. Unsur-unsur yang tergolong ke dalam logam berat antara lain As, $\mathrm{Cr}, \mathrm{Cu}, \mathrm{Mn}, \mathrm{Pb}, \mathrm{Zn}$ dan lainnya. Leaching logam berat dapat menyebabkan pencemaran tanah yang berujung pada pencemaran air tanah. Jang dkk. (2015) mengatakan geopolimer pada umumnya dapat membuat jumlah pori kapiler menjadi lebih sedikit apabila dibandingkan dengan beton konvensional yang menggunakan semen Portland sehingga leaching dapat diminimalkan. Pengujian TCLP mengikuti pedoman SW-846 method 1311 (USEPA 1992).

Tabel 2. Leaching test pada material precursor dan pasta geopolimer

\begin{tabular}{|c|c|c|c|c|c|}
\hline Kandungan & $\begin{array}{c}\text { GGBFS } \\
(\mathrm{mg} / \mathrm{L}) \\
\text { (Chen dkk., } \\
\text { 2018) }\end{array}$ & $\begin{array}{c}\text { Pasta } \\
\text { Geopolimer } \\
(\mathrm{mg} / \mathrm{L}) \\
\\
\text { (Chen dkk., } \\
2018)\end{array}$ & $\begin{array}{c}\text { GGBFS } \\
\text { (mg/L) } \\
\text { (Kubba } \\
\text { dkk., 2018) }\end{array}$ & $\begin{array}{c}\text { Fly Ash } \\
\text { (mg/L) } \\
\text { (Kubba dkk., } \\
\text { 2018) }\end{array}$ & $\begin{array}{c}\text { Batas TCLP } \\
(\mathrm{mg} / \mathrm{L}) \\
\\
\text { (Chen dkk., } \\
\text { 2018; Kubba } \\
\text { dkk., 2018) }\end{array}$ \\
\hline $\mathrm{Sb}$ & 0,0031 & $<B D$ & - & - & - \\
\hline As & 0,021 & $<B D$ & 0,034 & 0,093 & 5 \\
\hline $\mathrm{Ba}$ & 0,0116 & $<B D$ & - & - & 100 \\
\hline $\mathrm{Cd}$ & 0,007 & $<B D$ & TD & 0,011 & 1 \\
\hline $\mathrm{Cr}$ & $<B D$ & $<B D$ & TD & 0,294 & 5 \\
\hline $\mathrm{Cu}$ & 1,203 & 0,069 & 0,006 & 0,037 & 1 \\
\hline $\mathrm{Pb}$ & 0,014 & $<B D$ & TD & 0,024 & 5 \\
\hline $\mathrm{Ni}$ & 0,421 & 0,011 & 0,182 & 0,082 & 2 \\
\hline Co & 0,002 & $<B D$ & - & - & - \\
\hline $\mathrm{Se}$ & 0,071 & $<B D$ & - & - & 1 \\
\hline $\mathrm{Sr}$ & 2,003 & $<B D$ & - & - & - \\
\hline $\mathrm{Ag}$ & $<B D$ & $<B D$ & - & - & 5 \\
\hline $\mathrm{Zn}$ & 1,453 & 1,3 & 0,45 & 0,047 & 5 \\
\hline $\mathrm{Ti}$ & - & - & 0,012 & 0,008 & 2 \\
\hline $\mathrm{Be}$ & - & - & 0,004 & 0,019 & 0,5 \\
\hline
\end{tabular}

Keterangan: (-)= Tidak Disebutkan ; BD= Batas Deteksi; TD= Tidak Terdeteksi

Langkah prosedur ini secara singkat yaitu sampel dihancurkan dan disaring menggunakan saringan 9,5 mm. Sampel diekstrak dengan menggunakan cairan ekstraksi yaitu asam asetat yang diencerkan dengan air, kemudian dilanjutkan dengan mengukur $\mathrm{pH}$ dari sampel. Rasio solid material dengan cairan ekstraksi pada sampel adalah 1:20. Sampel yang telah diekstraksi diletakan di botol centrifuge, kemudian sampel diputar dengan kecepatan $30 \pm 2 \mathrm{rpm}$ menggunakan mesin selama $18 \pm 2$ jam. Hasil dari ekstraksi kemudian diberikan asam nitrat hingga $\mathrm{pH}$ mencapai kurang dari 2 . Kemudian, ekstrak disaring melalui filter berukuran 0,7 $\mu \mathrm{m}$. Sampel yang telah diekstrak kemudian dilakukan peninjauan kandungan logam beratnya (Alves dkk., 2014; Apithanyasai dkk., 2020). Penelitian Chen et al. (2018) menunjukan kadar logam berat pada material anorganik dan pasta geopolimer berada di bawah standar atau di bawah batas TCLP sehingga sampel ini dapat dikategorikan tidak memberikan dampak signifikan terhadap lingkungan. Tabel 3 menunjukan kandungan logam pada pasta lebih kecil dibanding dengan material precursor dan standar USEPA 1992 SW 846-1311. Hal ini membuktikan bahwa kandungan logam terikat erat pada proses geopolimerisasi sehingga leaching dapat diminimalisasi.

\section{KESIMPULAN}

Penggunaan material ferrous dan non-ferrous yang berasal dari produk sampingan pabrik dapat disimpulkan mampu memengaruhi karakteristik seperti kuat tekan dan kuat tarik belah pada beton geopolimer. Faktor yang memengaruhi kekuatan pada beton geopolimer adalah material, rasio $\mathrm{Na}_{2} \mathrm{SiO}_{3} / \mathrm{NaOH}$, serta metode dan durasi curing. Material seperti fly ash terak besi, terak nikel, nano silica, metakaolin, abu sekam padi dapat meningkatkan kuat tekan dan kuat tarik belah pada beton geopolimer. Meningkatkan rasio alkali aktivator $\mathrm{Na}_{2} \mathrm{SiO}_{3} / \mathrm{NaOH}$ dapat meningkatkan kekuatan beton geopolimer tetapi, penggunaan rasio yang terlalu besar dapat menyebabkan penurunan kekuatan pada beton geopolimer. Rasio alkali aktivator yang optimal untuk digunakan adalah berkisar 1 sampai 2. Metode dan durasi curing juga menjadi faktor yang memengaruhi kekuatan mekanik pada beton geopolimer. Meningkatkan suhu pada proses curing terbukti dapat meningkatkan kekuatan pada beton geopolimer dibandingkan dengan metode ambient curing. 
Suhu curing $60^{\circ} \mathrm{C}$ hingga $90^{\circ} \mathrm{C}$ merupakan suhu optimal dalam oven curing untuk beton geopolimer. Namun pada pengaplikasian di lapangan atau konstruksi dalam skala besar, pendekatan curing menggunakan metode oven curing sulit untuk dilakukan dibandingkan dengan penggunaan metode ambient curing dengan suhu ruang (AT). Kekuatan mekanik pada umur awal beton yang didapat dengan menggunakan metode ambient curing tidak melebihi kekuatan mekanik beton dengan metode oven curing. Berdasarkan tabel 1, kekuatan mekanik yang baik pada beton geopolimer dengan metode ambient curing dapat dicapai dengan menggunakan material precursor fly ash dan GGBFS.

TCLP merupakan prosedur pengujian kadar logam berat yang dapat merusak lingkungan. Pengujian TCLP pada pasta geopolimer tidak diperlukan karena kandungan logam berat yang terdeteksi dapat mencemari lingkungan sangat rendah dibandingkan dengan material precursor dan batas yang diizinkan. Hal ini dapat menghemat usaha dan biaya yang diperlukan. Melalui pengujian ini, potensi suatu sampel dalam mencemari lingkungan dapat diketahui. Kajian mengenai beton geopolimer perlu ditingkatkan khususnya durabilitas sehingga beton geopolimer dapat menggantikan peran beton konvensional.

\section{REFERENSI}

Abdul Sani, M. F. A., Muhamad, R., \& Mo, K. H. (2020). Effect of Ground Granulated Blast Furnace Slag as Partial Replacement in Fly Ash-Based Geopolymer Concrete. IOP Conference Series: Materials Science and Engineering,

https://doi.org/10.1088/1757-

899X/712/1/012002

Adam, A. A., \& Horianto. (2014). The effect of temperature and duration of curing on the strength of fly ash based geopolymer mortar. Procedia Engineering, 95(Scescm), 410-414. https://doi.org/10.1016/j.proeng.2014.12.199

Bouaissi, A., Li, L. yuan, Al Bakri Abdullah, M. M., \& Bui, Q. B. (2019a). Mechanical properties and microstructure analysis of FAGGBS-HMNS based geopolymer concrete. Construction and Building Materials, 210, 198-209.

https://doi.org/10.1016/j.conbuildmat.2019.03 .202

Bouaissi, A., Li, L. yuan, Al Bakri Abdullah, M. M., \& Bui, Q. B. (2019b). Mechanical properties and microstructure analysis of FAGGBS-HMNS based geopolymer concrete. Construction and Building Materials, 210, 198-209.

https://doi.org/10.1016/j.conbuildmat.2019.03
.202

Cao, R., Li, B., You, N., Zhang, Y., \& Zhang, Z. (2018). Properties of alkali-activated ground granulated blast furnace slag blended with ferronickel slag. Construction and Building Materials, 192, 123-132. https://doi.org/10.1016/j.conbuildmat.2018.10 .112

Chen, Z., Li, J. S., Zhan, B. J., Sharma, U., \& Poon, C. S. (2018). Compressive strength and microstructural properties of dry-mixed geopolymer pastes synthesized from GGBS and sewage sludge ash. Construction and Building Materials, 182, 597-607. https://doi.org/10.1016/j.conbuildmat.2018.06 .159

Chindaprasirt, P., Chareerat, T., \& Sirivivatnanon, V. (2007). Workability and strength of coarse high calcium fly ash geopolymer. Cement and Concrete Composites, 29(3), 224-229. https://doi.org/10.1016/j.cemconcomp.2006.1 1.002

Davidovits, J. (1991). Geopolymers - Inorganic polymeric new materials. Journal of Thermal Analysis, 37(8), https://doi.org/10.1007/BF01912193

Davidovits, J., \& Comrie, D. (1988). Long term durability of hazardous toxic and nuclear waste disposals. 1st European Conference on Soft Mineralurgy, Compiegne, France, 1(November) 125-134. http://scholar.google.com/scholar?hl=en\&bth $\mathrm{G}=$ Search\&q=intitle:Long+term+durability+of +hazardous+toxic+and+nuclear+waste+dispo sals\#0

Deb, P. S., Nath, P., \& Sarker, P. K. (2014). The effects of ground granulated blast-furnace slag blending with fly ash and activator content on the workability and strength properties of geopolymer concrete cured at ambient temperature. Materials and Design, 62 ,

32-39. https://doi.org/10.1016/j.matdes.2014.05.001

Demie, S., Nuruddin, M. F., \& Shafiq, N. (2013). Effects of micro-structure characteristics of interfacial transition zone on the compressive strength of self-compacting geopolymer concrete. Construction and Building Materials, 41(2013), 91-98. https://doi.org/10.1016/j.conbuildmat.2012.11 .067

Duxson, P., Fernández-Jiménez, A., Provis, J. L., Lukey, G. C., Palomo, A., \& Van Deventer, J. S. J. (2007). Geopolymer technology: The current state of the art. Journal of Materials Science, 42(9), 29172933. https://doi.org/10.1007/s10853-0060637-z 
Farhan, N. A., Sheikh, M. N., \& Hadi, M. N. S. (2019). Investigation of engineering properties of normal and high strength fly ash based geopolymer and alkali-activated slag concrete compared to ordinary Portland cement concrete. Construction and Building Materials, 196, 26-42. https://doi.org/10.1016/j.conbuildmat.2018.11 .083

Ferdous, W., Manalo, A., Khennane, A., \& Kayali, O. (2015). Geopolymer concrete-filled pultruded composite beams - Concrete mix design and application. Cement and Concrete Composites, 58(2015), 1-13. https://doi.org/10.1016/j.cemconcomp.2014.1 2.012

Hardjito, D., \& Rangan, B. V. (2005). Development and Properties of Low-calcium Fly Ash Based Geopolymer LOW-CALCIUM FLY ASH-BASED GEOPOLYMER CONCRETE By Faculty of Engineering Curtin University of Technology. January, 48.

Hardjito, D., Wallah, S. E., Sumajouw, D. M. J., \& Rangan, B. V. (2004). On the development of fly ash-based geopolymer concrete. $\mathrm{ACl}$ Materials Journal, 101(6), 467-472. https://doi.org/10.14359/13485

Hassan, A., Arif, M., \& Shariq, M. (2019). Use of geopolymer concrete for a cleaner and sustainable environment - A review of mechanical properties and microstructure. Journal of Cleaner Production, 223, 704-728. https://doi.org/10.1016/j.jclepro.2019.03.051

Jang, J. G., Ahn, Y. B., Souri, H., \& Lee, H. K. (2015). A novel eco-friendly porous concrete fabricated with coal ash and geopolymeric binder: Heavy metal leaching characteristics and compressive strength. Construction and Building Materials, 79, 173-181. https://doi.org/10.1016/j.conbuildmat.2015.01 .058

Jawahar J. G, M. G. (2015). Strength properties of fly ash and GGBS based geo-polymer concrete. International Journal of ChemTech Research, 9(3), 350-356.

Jithendra, C., \& Elavenil, S. (2019). Role of superplasticizer on GGBS based Geopolymer concrete under ambient curing. Materials Today: Proceedings, 18, 148-154. https://doi.org/10.1016/j.matpr.2019.06.288

Kirschner, A. V., \& Harmuth, H. (2004). Investigation of geopolymer binders with respect to their application for building materials. Ceramics - Silikaty, 48(3), 117120.
Kong, D. L. Y., Sanjayan, J. G., \& SagoeCrentsil, K. (2008). Factors affecting the performance of metakaolin geopolymers exposed to elevated temperatures. Journal of Materials Science, 43(3), 824-831. https://doi.org/10.1007/s10853-007-2205-6

Kubba, Z., Fahim Huseien, G., Sam, A. R. M., Shah, K. W., Asaad, M. A., Ismail, M. Tahir, M. M., \& Mirza, J. (2018). Impact of curing temperatures and alkaline activators on compressive strength and porosity of ternary blended geopolymer mortars. Case Studies in Construction Materials, 9, e00205. https://doi.org/10.1016/j.cscm.2018.e00205

Kusbiantoro, A., Nuruddin, M. F., Shafiq, N., \& Qazi, S. A. (2012). The effect of microwave incinerated rice husk ash on the compressive and bond strength of fly ash based geopolymer concrete. Construction and Building Materials, 36, 695-703. https://doi.org/10.1016/j.conbuildmat.2012.06 .064

Lloyd, N. A., \& Rangan, B. V. (2010). Geopolymer concrete with fly ash. 2nd International Conference on Sustainable Construction Materials and Technologies, 7, 1493-1504.

McLellan, B. C., Williams, R. P., Lay, J., Van Riessen, A., \& Corder, G. D. (2011). Costs and carbon emissions for geopolymer pastes in comparison to ordinary portland cement. Journal of Cleaner Production, 19(9-10), 1080-1090.

https://doi.org/10.1016/j.jclepro.2011.02.010

Mehta, A., \& Siddique, R. (2018). Sustainable geopolymer concrete using ground granulated blast furnace slag and rice husk ash: Strength and permeability properties. Journal of Cleaner Production, 205, 49-57. https://doi.org/10.1016/j.jclepro.2018.08.313

Nath, P., \& Sarker, P. K. (2014). Effect of GGBFS on setting, workability and early strength properties of fly ash geopolymer concrete cured in ambient condition. Construction and Building Materials, 66, 163-171. https://doi.org/10.1016/j.conbuildmat.2014.05 .080

Nath, P., Sarker, P. K., \& Rangan, V. B. (2015). Early age properties of low-calcium fly ash geopolymer concrete suitable for ambient curing. Procedia Engineering, 125, 601-607. https://doi.org/10.1016/j.proeng.2015.11.077

Neupane, K. (2018). High-Strength Geopolymer Concrete- Properties, Advantages and Challenges. Advances in Materials, 7(2), 15. https://doi.org/10.11648/j.am.20180702.11 
Nuaklong, P., Sata, V., \& Chindaprasirt, P. (2018). Properties of metakaolin-high calcium fly ash geopolymer concrete containing recycled aggregate from crushed concrete specimens. Construction and Building Materials, $\quad 161, \quad 365-373$. https://doi.org/10.1016/j.conbuildmat.2017.11 .152

Nuruddin, M. F., Demie, S., Ahmed, M. F., \& Shafiq, N. (2011). Effect of superplasticizer and $\mathrm{NaOH}$ molarity on workability, compressive strength and microstructure properties of self-compacting geopolymer concrete. World Academy of Science, Engineering and Technology, 51(3), 907914. https://doi.org/10.5281/zenodo.1062742

Parveen, Singhal, D., Junaid, M. T., Jindal, B. B., \& Mehta, A. (2018). Mechanical and microstructural properties of fly ash based geopolymer concrete incorporating alccofine at ambient curing. Construction and Building Materials, 180(2018), 298-307. https://doi.org/10.1016/j.conbuildmat.2018.05 .286

Patel, Y. J., \& Shah, N. (2018). Enhancement of the properties of Ground Granulated Blast Furnace Slag based Self Compacting Geopolymer Concrete by incorporating Rice Husk Ash. Construction and Building Materials, 171, 654-662. https://doi.org/10.1016/j.conbuildmat.2018.03 .166

Rangan, B. V. (2008). FLY ASH-BASED GEOPOLYMER CONCRETE (Column). Engineering Faculty Curtin University of Technology Perth, Australia, 3124-3130. https://doi.org/10.1007/s10853-006-0523-8

Saini, G., \& Vattipalli, U. (2020). Assessing properties of alkali activated GGBS based self-compacting geopolymer concrete using nano-silica. Case Studies in Construction Materials, $\quad 12, \quad$ e00352. https://doi.org/10.1016/j.cscm.2020.e00352

Thaarrini, J., \& Venkatasubramani, R. (2015). Feasibility Studies on Compressive Strength of Ground Coal Ash Geopolymer Mortar. Periodica Polytechnica Civil Engineering, 59(3), 373-379. https://doi.org/10.3311/ppci.7696

Topark-Ngarm, P., Chindaprasirt, P., \& Sata, V. (2015). Setting time, strength, and bond of high-calcium fly ash geopolymer concrete. Journal of Materials in Civil Engineering, 27(7), $1-7$. https://doi.org/10.1061/(ASCE)MT.19435533.0001157
Umniati, B. S., Risdanareni, P., \& Zein, F. T. Z. (2017). Workability enhancement of geopolymer concrete through the use of retarder. AIP Conference Proceedings, 1887(September).

https://doi.org/10.1063/1.5003516

Van Den Heede, P., \& De Belie, N. (2012). Environmental impact and life cycle assessment (LCA) of traditional and "green" concretes: Literature review and theoretical calculations. Cement and Concrete Composites, 34(4), 431-442. https://doi.org/10.1016/j.cemconcomp.2012.0 1.004

Venkatesan, R. P., \& Pazhani, K. C. (2016). Strength and durability properties of geopolymer concrete made with Ground Granulated Blast Furnace Slag and Black Rice Husk Ash. KSCE Journal of Civil Engineering, 20(6), 2384-2391. https://doi.org/10.1007/s12205-015-0564-0

Vora, P. R., \& Dave, U. V. (2013). Parametric studies on compressive strength of geopolymer concrete. Procedia Engineering, 51 , 210-219. https://doi.org/10.1016/j.proeng.2013.01.030

Wallah, S. E., \& Rangan, B. V. (2006). LowCakcium Fly Ash Based. 1-107. https://espace.curtin.edu.au/handle/20.500.1 $1937 / 34322$

Xie, J., Chen, W., Wang, J., Fang, C., Zhang, B., \& Liu, F. (2019). Coupling effects of recycled aggregate and GGBS/metakaolin on physicochemical properties of geopolymer concrete. Construction and Building Materials, 226, 345-359. https://doi.org/10.1016/j.conbuildmat.2019.07 .311

Yang, T., Yao, X., \& Zhang, Z. (2014). Geopolymer prepared with high-magnesium nickel slag: Characterization of properties and microstructure. Construction and Building Materials, 59, 188-194. https://doi.org/10.1016/j.conbuildmat.2014.01 .038

Yip, C. K., Lukey, G. C., Provis, J. L., \& van Deventer, J. S. J. (2008). Effect of calcium silicate sources on geopolymerisation. Cement and Concrete Research, 38(4), 554564.

https://doi.org/10.1016/j.cemconres.2007.11. 001 